A N N A L E S

U N IVERSITATIS MARIAE C URIE-SK七O D OW S K A

L UBLIN - POLONIA

VOL. LXXIII

SECTIO B

2018

JOLANTA LATOSIŃSKA

ORCID ID 0000-0003-4886-7853

Wydział Nauk Geograficznych

Uniwersytet Łódzki

jolanta.latosinska@geo.uni.lodz.pl

\author{
BEATA MEYER \\ ORCID ID 0000-0001-9730-7532 \\ Wydział Zarządzania i Ekonomiki Usług \\ Uniwersytet Szczeciński \\ beata.meyer@wzieu.pl
}

\title{
Konsekwencje przekształcania elementów krajobrazu w atrakcje turystyczne
}

The consequences of transforming landscape elements into tourist attractions

\begin{abstract}
The constant dynamic development of tourism is currently causing a growing interest in finding new places and objects which can become attractive for tourists. Many possibilities are created by the use of landscape and its elements, the uniqueness of which allows for the creation of tourist attractions of various types. Simultaneously, making landscape available to tourists in the form of a tourist attraction has diverse consequences. Those effects can be positive or neutral, but it is increasingly more common for them to be negative. Landscape elements transformed into tourist attractions can become dominants of that landscape, and, with time, become a (positive or negative) symbol of a given place or area. The creation of tourist attractions based on landscape elements results in the modification of existing landscape and the creation of transformed landscape. Making too many changes to the original shape of the landscape can increase the landscape's tourist attractiveness as well as (which is more often the case) cause the decrease of its attractiveness to tourists. The aim of the article is to highlight the increasing usage of landscape elements in the process of creating tourist attractions and to identify the consequences of that process. The article is a review and from the methodological point of view the major role in its creation has been played by the methods of field research: observation, participant observation, experiencing attractions and photographic documentations. The result of reflections on the effects of transformations related to the tourist development of tourist attractions is the attempt to classify them and exemplify them.
\end{abstract}

Keywords: landscape, tourist attractions, tourism, landscape transformation

Abstrakt: Stały, dynamiczny rozwój turystyki powoduje poszukiwanie coraz to nowych miejsc i obiektów, które mogą stać się atrakcyjne dla turystów. Duże możliwości stwarza wykorzystanie krajobrazu i jego elementów, ale kreowanie atrakcji turystycznych tego typu powoduje zróżnicowane konsekwencje, które coraz częściej mają charakter negatywny. Atrakcje turystyczne mogą dominować w krajobrazie, a z czasem stać się (pozytywnym lub negatywnym) symbolem danego miejsca czy obszaru. Modyfikacja istniejącego krajobrazu może zarówno zwiększyć jego 
atrakcyjność turystyczną, jak i (co dzieje się częściej) spowodować zmniejszenie jego atrakcyjności dla turystów. Celem artykułu jest wskazanie na coraz częstsze wykorzystanie elementów krajobrazu w procesie kreowania atrakcji turystycznych oraz identyfikacja konsekwencji tego procesu. Artykuł ma charakter przeglądowy i z metodologicznego punktu widzenia największą rolę w jego powstaniu odegrały metody badań terenowych: obserwacja, obserwacja uczestnicząca, doświadczanie atrakcji i dokumentacja fotograficzna. Rezultatem rozważań nad skutkami podejmowanych przekształceń związanych z turystycznym rozwojem atrakcji turystycznych jest próba ich klasyfikacji i egzemplifikacja.

Słowa kluczowe: krajobraz, atrakcje turystyczne, turystyka, przekształcenia krajobrazu

\section{WYKORZYSTANIE KRAJOBRAZU DLA KREOWANIA ATRAKCJI TURYSTYCZNYCH}

Krajobraz jest jednym z pojęć, które wydaje się powszechnie znane i rozumiane, przy czym jego definiowanie ma wówczas najczęściej charakter intuicyjny, identyfikujący krajobraz z jego wizualną percepcją, chociaż na postrzeganie krajobrazu silny wpływ mają także inne zmysły i cechy kulturowe obserwatora, a także wykreowany wizerunek danego obszaru (Kulczyk 2010). Widoczny wzrost znaczenia krajobrazu w ostatnich kilku dekadach przejawia się przede wszystkim w kontekście paradygmatu zrównoważonego rozwoju, ale także jakości życia (w tym wypoczynku związanego z turystyką i rekreacją) oraz stałej ekspansji działalności człowieka, która zmienia zastaną przestrzeń na wielu płaszczyznach. W konsekwencji pojawiło się wiele definicji pojęcia krajobrazu (i ciągle powstają nowe), na gruncie różnych dyscyplin naukowych, dla których krajobraz stał się (lub zawsze był) istotnym przedmiotem badań. Definicje te uwypuklają różne aspekty krajobrazu w zależności od tego, jakich obszarów dotyczą. Najczęściej krajobraz jest rozumiany jako ogół wzajemnie powiązanych cech przyrodniczych i antropogenicznych, tworzących charakterystyczny obraz powierzchni ziemi wyróżniający określony obszar (Szulczewska 2009). W sposób pełny, a jednocześnie na tyle syntetyczny, że może być wykorzystany w różnych kontekstach badawczych, krajobraz został zdefiniowany w Europejskiej Konwencji Krajobrazowej jako „obszar postrzegany przez ludzi, którego charakter jest wynikiem działania i interakcji czynników przyrodniczych i/lub ludzkich” (EU 2000). Krajobraz zajmuje wycinek przestrzeni, posiada określoną fizjonomię, jest systemem dynamicznym, którego sposób funkcjonowania zależy od charakteru części składowych i powiązań pomiędzy nimi, a także podlega ewolucji. O specyfice wizualnej obszaru i jego niepowtarzalności decyduje ogół cech krajobrazowych wyróżniających dany teren (Walczak 2007). W zależności od stopnia ingerencji człowieka wyróżnia się krajobrazy pierwotne, naturalne, kulturowe, harmonijne lub zdegradowane (Bieńczyk 2003). Za najbardziej atrakcyjne uważa się krajobrazy harmonijne, z licznymi 
wyraźnymi i ciągłymi planami, wzbogacone wieloma zróżnicowanymi elementami (o wysokim poziomie estetyki) o dobrze rozwiniętym pionowo układzie elementów krajobrazu, zarówno w układzie horyzontalnym, jak i w perspektywie piętrowej. Jego atrakcyjność podnosi wysoka kontrastowość sąsiadujących składników krajobrazu (Meyer 2008).

W kontekście stałego wzrostu liczby turystów oraz dywersyfikacji ich zainteresowań i potrzeb (związanych z nowymi trendami, które dotyczą zarówno charakteru podejmowanych aktywności, jak i kierunku wyjazdów) poszukiwane i kreowane są coraz to nowe atrakcje turystyczne, przy jednoczesnym przekształcaniu atrakcji już istniejących. Krajobraz, którego standardowe funkcje turystyczne wynikają z jego atrakcyjności, przydatności i estetyki (odpowiednio: przyciaganie turystów, fizyczne podstawy lokalizacji różnych form turystyki, charakter podejmowanej aktywności, Pietrzak 2008), dysponując wyjątkowym i zróżnicowanym potencjałem, staje się wyjątkowo atrakcyjnym obszarem dla kreowania obiektów mogących sprostać oczekiwaniom turystów (szerzej o relacjach turystyka-krajobraz m.in. Myga-Piątek 2016; Kulczyk 2014).

Pojęcie atrakcji turystycznych zostało wprowadzone do literatury fachowej przez Cohena w 1972 r. i najczęściej oznaczają one wszelkie obiekty stanowiące przedmiot zainteresowania turystów i przyciągające ruch turystyczny lub wszystkie elementy skłaniające turystów do opuszczenia domu (Kruczek 2005). W ujęciu produktowym zaś atrakcja turystyczna oznacza system składający się z jądra/rdzenia (czyli miejsca/obiektu), oznacznika (czyli dostępnej informacji o miejscu/obiekcie) oraz turysty (Kruczek 2011).

Coraz częściej spośród wszystkich elementów składających się na krajobraz (będący jedynie tłem dla realizowanej aktywności turystycznej) wyodrębnia się jeden składnik (lub ich grupę) i w sposób zaplanowany (lub równie często zupełnie przypadkowy) na tej bazie powstają atrakcje turystyczne. Najczęściej zainteresowanie turystów budzą dominujące elementy krajobrazu zarówno ze względu na łatwą identyfikację przestrzenna, jak i przyrodniczy czy kulturowy kontekst (Meyer 2012). Dominanty krajobrazowe to elementy stanowiące punkty orientacyjne, widoczne z daleka i pozostające w pamięci turystów. Określają one charakter krajobrazu, sprawiając, że jest on możliwy do zidentyfikowania, a nawet unikatowy. Dominanty wyróżnia najczęściej: skala odbiegająca od otoczenia, wyrazista forma, barwa, struktura lub funkcja i przeznaczenie (Vogt, Nassery 2008). Nieco mniejszą siłę oddziaływania mają subdominanty, czyli elementy wyróżniające się w krajobrazie, ale ze względu na sąsiedztwo dominant postrzegane jako mniejsze, oraz akcenty, wyróżniające się poprzez swoją odmienność, a nie gabaryty (odmienność może wynikać z formy bądź koloru, może być także sezonowo zmienna). 
Atrakcje turystyczne wykorzystujące zróżnicowane elementy krajobrazu można pogrupować w zależności od ich genezy i formy na powstające w oparciu o (WAll 1997):

1. Komponenty przyrodnicze, w tym:

a) punktowe - np. formy skalne, występujące pojedynczo lub w grupach, wodospady, pojedyncze drzewa lub grupy drzew, które mogą mieć również kontekst kulturowy lub częściej religijny,

b) powierzchniowe - np. obejmujące elementy przyrodnicze tworzące większe skupiska w krajobrazie, najczęściej mające charakter obszarów chronionych,

c) liniowe - np. linia styku morze/ląd,

2. Komponenty antropogeniczne, w tym:

a) punktowe - np. obiekty sakralne, obronne, rezydencjonalne, infrastrukturalne,

b) powierzchniowe - np. uprawy charakterystyczne dla danych regionów, które w odpowiednich okresach/porach roku budzą zainteresowanie turystów,

c) liniowe - np. linowa infrastruktura komunikacyjna (w ujęciu historycznymi i współczesnym).

Powstanie atrakcji turystycznej wymaga rozwoju infrastruktury turystycznej i paraturystycznej (transportowej, noclegowej, gastronomicznej, usługowo-handlowej, rozrywkowej), co przyczynia się do przekształcenia krajobrazu pierwotnego i wpływa na jego ocenę przez turystów. Często ocena jest dokonywana w sposób podświadomy i subiektywny, ale ma bardzo istotne znaczenie dla ostatecznej oceny poziomu atrakcyjności turystycznej obszaru, ponieważ bez względu na charakter realizowanej podróży krajobraz zawsze zostanie przez turystę dostrzeżony i oceniony. Już ponad dekadę temu badania przeprowadzone wśród niemieckich turystów wykazały, że 75\% z nich czuje się psychicznie zmęczonych i zniechęconych, wypoczywając w otoczeniu krajobrazów, które straciły swój naturalny charakter (Bastian 2015).

Celem opracowania jest wskazanie na coraz częstsze wykorzystanie elementów krajobrazu w procesie kreowania atrakcji turystycznych oraz identyfikacja konsekwencji tego procesu. Artykuł ma charakter przeglądowy i z metodologicznego punktu widzenia największą rolę w jego powstaniu odegrały metody badań terenowych: obserwacja, obserwacja uczestnicząca, doświadczanie atrakcji oraz dokumentacja fotograficzna. Rezultatem rozważań nad skutkami podejmowanych przekształceń związanych z turystycznym rozwojem atrakcji turystycznych jest próba ich klasyfikacji i egzemplifikacja. 


\section{KONSEKWENCJE TWORZENIA ATRAKCJI TURYSTYCZNYCH W OPARCIU O ELEMENTY KRAJOBRAZU}

Nie ma atrakcji turystycznych bez turystów, a każdy element krajobrazu udostępniony do zwiedzania może stanowić samodzielną atrakcję. To właśnie na potrzeby turystów elementy krajobrazu są przekształcane i dopóki będą cieszyć się zainteresowaniem odwiedzających, dopóty pozostaną atrakcjami turystycznymi (bez względu na rodzaj tych przekształceń). Często „z pojęciem krajobrazu utożsamiana jest jego wizualna percepcja, chociaż na postrzeganie krajobrazu silny wpływ mają także inne zmysły oraz cechy kulturowe obserwatora i wykreowany wizerunek danego obszaru” (Meyer 2012). Bardzo ważny jest więc odbiór atrakcji przez odwiedzających. Postrzeganie atrakcji turystycznych może być pozytywne/neutralne lub negatywne i nie ma znaczenia, czy jest to krajobraz przyrodniczy czy antropogeniczny.

Atrakcje turystyczne - punktowe, powierzchniowe czy liniowe - często powstają w oparciu o dominanty krajobrazu, które kształtują wyrazisty jego wygląd, identyfikują i definiują go, są widoczne z daleka, stanowią punkty orientacyjne, przyciągają uwagę i pozostają w pamięci. Atrakcje turystyczne często urastają do rangi symbolu, przykuwają uwagę turystów, intrygują. Jako symbole stają się „znakami umownymi”, które oddają pewne głębiej ukryte treści, przekazują informacje, inspirują do myślenia, są odpowiednikami pojęć postrzeganych zmysłowo. Są zazwyczaj obrazami lub znakami wizualnymi wyrażającymi głębszą ideę, przekaźnikami prawdy uniwersalnej, często coś utrwalają i jako wyraz pamięci istnieją w świadomości. Chętnie się do symboli odwołujemy, za pomocą symboli zachowujemy i przechowujemy pamięć (Krakowiak, Latosińska 2012).

Jednak należy podkreślić, że relacja pomiędzy elementami krajobrazu (w tym dominantami) a atrakcjami turystycznymi ma charakter dwustronny. Elementy krajobrazu mogą stać się atrakcjami turystycznymi, podobnie jak powstające atrakcje mogą tworzyć, wzbogacać czy wręcz kreować krajobraz przyrodniczy i kulturowy. To wzbogacanie lub kreowanie wiąże się zazwyczaj z rozbudową infrastruktury turystycznej i paraturystycznej. Atrakcje turystyczne najczęściej w sposób kompleksowy definiują charakter krajobrazu, często w sposób zupełnie odmienny od pierwotnego. Ze względu na masowy charakter współczesnej turystyki można powiedzieć, że atrakcje turystyczne w sposób agresywny zawłaszczają przestrzeń (Meyer 2012).

Konsekwencją przekształcania krajobrazu jako środowiska rozwoju turystyki jest jego zmienność i utrata trwałości/tożsamości. W konsekwencji w poszukiwaniu własnego wizerunku krajobraz traci swoją autentyczność, stając się makietą lub hybrydą (Myga-Piątek 2016). 
Zasadniczym tematem artykułu są konsekwencje przekształcania elementów krajobrazu w atrakcje turystyczne. Zdaniem W. Kopalińskiego (1999) konsekwencja (łac. consequentia) to „wynik, skutek, rezultat; logiczne następstwo faktów; logiczna ciaggłość w działaniu; postępowanie oparte na ściśle określonych zasadach, zgodnie z powziętym planem [...]”. W przypadku tworzenia atrakcji turystycznych konsekwencje/następstwa mają bardzo zróżnicowany charakter i można je rozpatrywać wieloaspektowo, w odniesieniu do:

- środowiska przyrodniczego, antropogenicznego, społeczno-ekonomicznego itd., czyli szeroko pojętego środowiska geograficznego,

- krajobrazu, będącego syntezą środowiska geograficznego,

- turystyki, czyli zjawiska rozpatrywanego w płaszczyźnie przestrzennej, ekonomicznej, prawnej, społecznej, psychologicznej i kulturowej,

- turysty jako podmiotu ruchu turystycznego wraz z jego potrzebami i pragnieniami,

- atrakcji turystycznych, które powstają w wyniku relacji człowieka/turysty do przedmiotu/elementu odwiedzanego,

- wszystkich powyższych czynników uwzględnianych jednocześnie lub dowolnych ich kombinacji.

Rozpatrując relacje dwustronne pomiędzy elementami krajobrazu a atrakcjami turystycznymi, należy wziąć pod uwagę:

1) charakter tych konsekwencji, które zostały na potrzeby opracowania określone jako pozytywne/neutralne lub negatywne,

2) czas ujawnienia się konsekwencji określonych jako konsekwencje widoczne ze skutkiem natychmiastowym lub przeniesione w czasie (opóźnione),

3) rodzaj konsekwencji określonych jako bezpośrednie i pośrednie; trwałe, tymczasowe (np. sezonowe) lub incydentalne; zamierzone lub przypadkowe.

Przyjmując za K. Przecławskim (1997), że turystyka jest „całokształtem zjawisk ruchliwości przestrzennej związanych z dobrowolną czasową zmianą miejsca pobytu, rytmu i środowiska życia oraz wejściem w styczność osobistą ze środowiskiem odwiedzanym [...]”, należy uznać, że rozwój turystyczny obiektu, miejscowości czy obszaru niesie określone konsekwencje. Biorąc pod uwagę relacje: krajobraz-turysta-turystyka-atrakcje turystyczne, uznano, że konsekwencje turystycznego rozwoju dla środowiska mogą być pozytywne/ neutralne lub negatywne i można je rozpatrywać w różnych ujęciach czy kontekstach omówionych poniżej.

1. Kontekst przestrzenny - kreowanie atrakcji wiąże się często ze zmianami przestrzennymi, pojawiają się nowe obiekty lub dotychczasowe zostają zmienione. Jeżeli te zmiany nie wpływają negatywnie na krajobraz, to w przestrzeni pojawia się nowy element udostępniony do zwiedzania i to jest pozytywne. 
Jeżeli natomiast zmiany te mają charakter agresywny, zawłaszczający miejsce czy obszar dla celów turystycznych, wówczas konsekwencje są negatywne.

2. Kontekst kulturowy - turystyka to spotkanie kultur, to sposób bycia z innymi, to przejmowanie pewnych wzorców, stylu życia. Nadmierny kontakt z przybyszami z zewnątrz (turystami) może prowadzić do zaniedbań w zakresie podtrzymywania miejscowych tradycji. $Z$ drugiej zaś strony pewne zwyczaje i tradycje mogą być pielęgnowane ze względu na zainteresowanie turystów lokalnymi obrzędami.

3. Kontekst ekonomiczny - wszelkie inwestycje turystyczne przyczyniają się do rozwoju przemysłu turystycznego i turystycznego biznesu, którym rządzą prawa popytu i podaży często z pominięciem oczekiwań ludności miejscowej.

4. Kontekst prawny - chodzi tutaj zarówno o wszelkie ograniczenia prawne dotyczące podróżowania, przekraczania granic, jak i o ochronę dóbr natury i kultury. Prawo w dbałości o środowisko ogranicza czasami w mniejszym lub większym zakresie dostęp do atrakcji turystycznych i powinniśmy się tym ograniczeniom podporząqkować.

5. Kontekst społeczny - podróże turystyczne często mają charakter masowy, odbywają się w grupach, w których człowiek przyjmuje rolę turysty. Często zachowuje się tak jak inni uczestnicy grupy i nie zawsze te zachowania są pozytywne, np. są zbyt głośne, naruszają spokój obszarów, które wymagają ciszy ze względu na unikatowość świata roślin i zwierząt.

6. Kontekst psychologiczny - człowiek potrzebuje zmiany środowiska życia, odmienności, poznania. Jest podmiotem turystycznych migracji, ale z natury jest też zawodny, wywołuje konflikty i zachowuje się nieodpowiednio. Ważne jest więc świadome podróżowanie, rozumienie odmienności obszarów odwiedzanych, zarówno krajobrazu naturalnego, jak i kulturowego.

\section{WYBRANE PRZYKŁADY OBRAZUJACCE KONSEKWENCJE PRZEKSZTAŁCANIA ELEMENTÓW KRAJOBRAZU W ATRAKCJE TURYSTYCZNE}

Na potrzeby opracowania, dla zilustrowania konsekwencji przekształceń, zostały przedstawione przykłady atrakcji turystycznych z różnych zakątków świata, które mogą wydawać się dość przypadkowe (na świecie jest ich przecież tysiące), ale ta przypadkowość była zamierzona i celowa. Wybór zaprezentowanych miejsc był podyktowany własnymi podróżami turystycznymi, podróżami znajomych i literatura. Jak można zauważyć, podczas podejmowanych podróży, różne elementy krajobrazu przyciągają naszą uwagę i różne atrakcje wzbudzają zainteresowanie. Wykorzystanie niektórych z nich może budzić kontrowersje, bowiem postrzeganie tych atrakcji jest bardzo subiektywne. Niezależnie jednak 
od tego, z lepszym czy gorszym skutkiem, ale należy podejmować próbę oceny konsekwencji/skutków, jakie niesie przekształcanie elementów krajobrazu w atrakcje turystyczne.

\section{Konsekwencje pozytywne/neutralne}

ATRAKCJE POWIERZCHNIOWE

1) Ta Van i Cat Cat to wioski Hmongów w okolicach kurortu Sa Pa w Wietnamie (Prowincji Lào Cai). Hmongowie trudnią się rolnictwem, głównie uprawą ryżu, szyją tradycyjne stroje, haftują ubrania, wyrabiają srebrne ozdoby. Zachowali swoją kulturę, język, zwyczaje i religie. Turyści zwiedzają wioskę indywidualnie, przyglądają się, jak toczy się zwyczajne życie Hmongów. Spacerują bez przewodnika i wpisują się w reguły życia miejscowej ludności. W tym przypadku, codzienność i zwyczajność stają się atrakcją. Konsekwencje takiego udostępniania atrakcji turystycznych są pozytywne. Obcowanie z ludnością w naturalnym dla niej środowisku to najlepszy sposób poznawania kultury rdzennych plemion (fot. 1).

2) Pola tulipanów w Holandii i Ogrody Keukenhof w Lisse (niedaleko Amsterdamu). Uprawa tulipanów w tym kraju traktowana jest jako uprawa narodowa. To wyjątkowa atrakcja, znana na całym świecie, ale niestety sezonowa (przemijająca). Tulipanowe pola i ogrody najpiękniej wyglądają w połowie kwietnia. Aby uniknać wydeptywania upraw, ruch turystyczny skoncentrowano w Ogrodach Keukenhof. Tulipanowe pola Holandii w naturalny sposób wpisują się w krajobraz i nieustannie zachwycają miłośników tych kwiatów (fot. 2).

\section{ATRAKCJE LINIOWE}

1) Praia da Ursa to inaczej Plaża Niedźwiedzia nad Atlantykiem w Portugalii (niedaleko Sintry). Swoją nazwę zawdzięcza formie skalnej kształtem przypominającej niedźwiedzia. Jest to niewielka, piaszczysta plaża otoczona klifowym brzegiem i licznymi skałami. Klif jest wysoki, przez co plaża jest trudno dostępna. Na klifie znajduje się niewielki parking, z którego na plażę wiodą wąskie ścieżki bez oznakowania. Turyści mówią że to wyjątkowo urokliwe miejsce bez tłumu ludzi, plaża marzeń. Jest to niepowtarzalna atrakcja turystyczna stworzona przez naturę, bardzo pozytywnie odbierana przez wypoczywających, a brzeg klifowy broni do niej dostępu (fot. 3).

2) Droga Trolli w Norwegii (Trollstigen) jest położona na południe od Andalsnes, w gminie Rauma. Składa się z 11 serpentyn, w większości zakręcających pod katem $180^{\circ}$. Przy Trollstigen znajduje się prawdopodobnie jedyny na świecie znak drogowy „Uwaga Trolle”. To atrakcja bardzo dobrze wkomponowana w krajobraz, wyposażona w parkingi, minimalną infrastrukturę gastronomiczną 


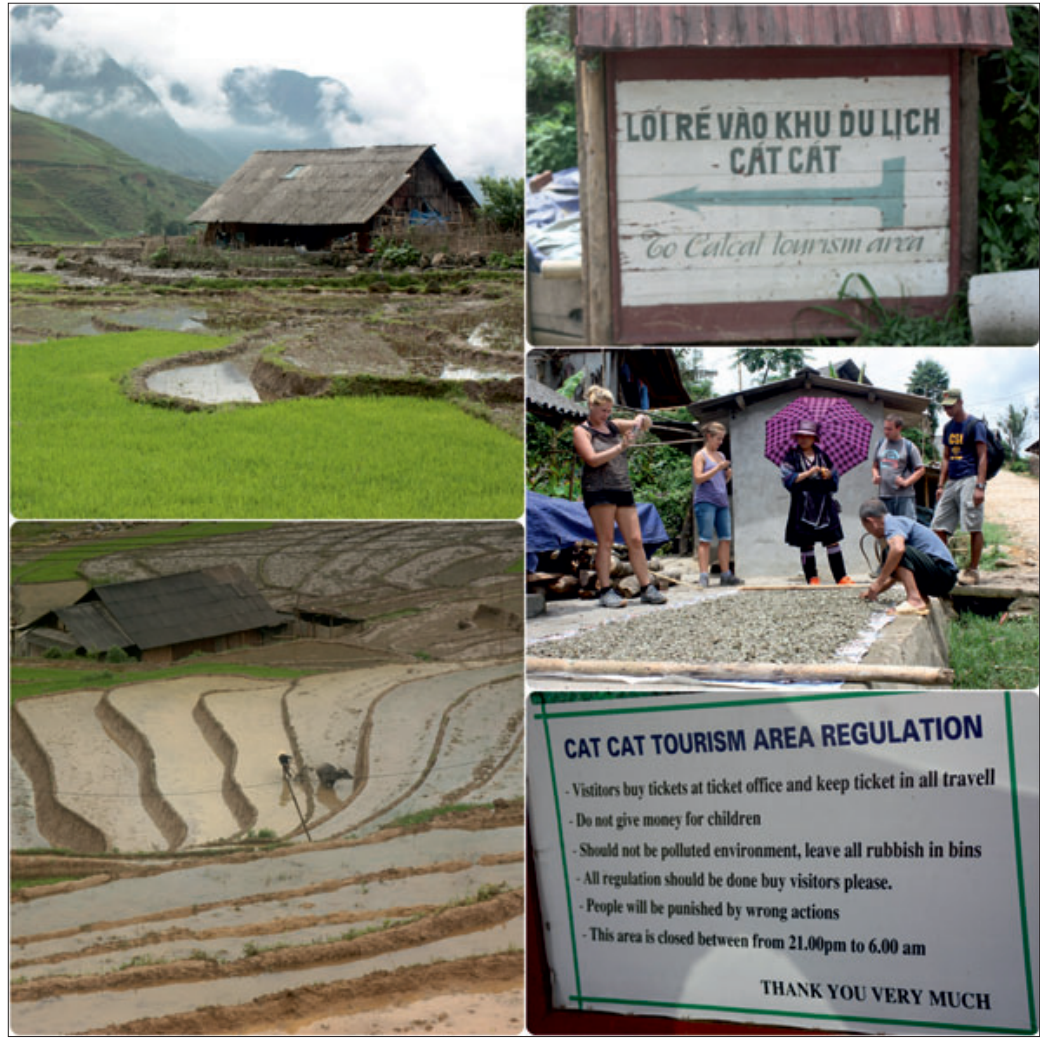

Fot. 1. Ta Van i Cat Cat (Wietnam) (fot. B. Krakowiak) Photo 1. Ta Van and Cat Cat (Vietnam) (photo: B. Krakowiak)

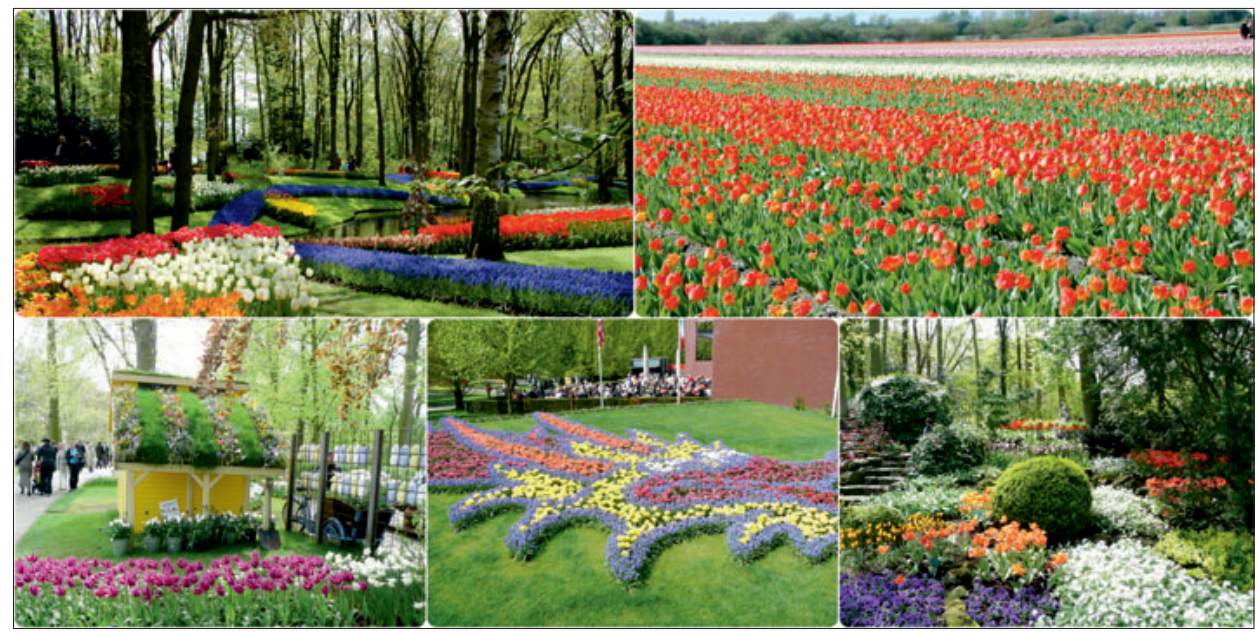

Fot. 2. Keukenhof (Holandia) (fot. B. Meyer)

Photo 2. Keukenhof (Netherlands) (photo: B. Meyer) 


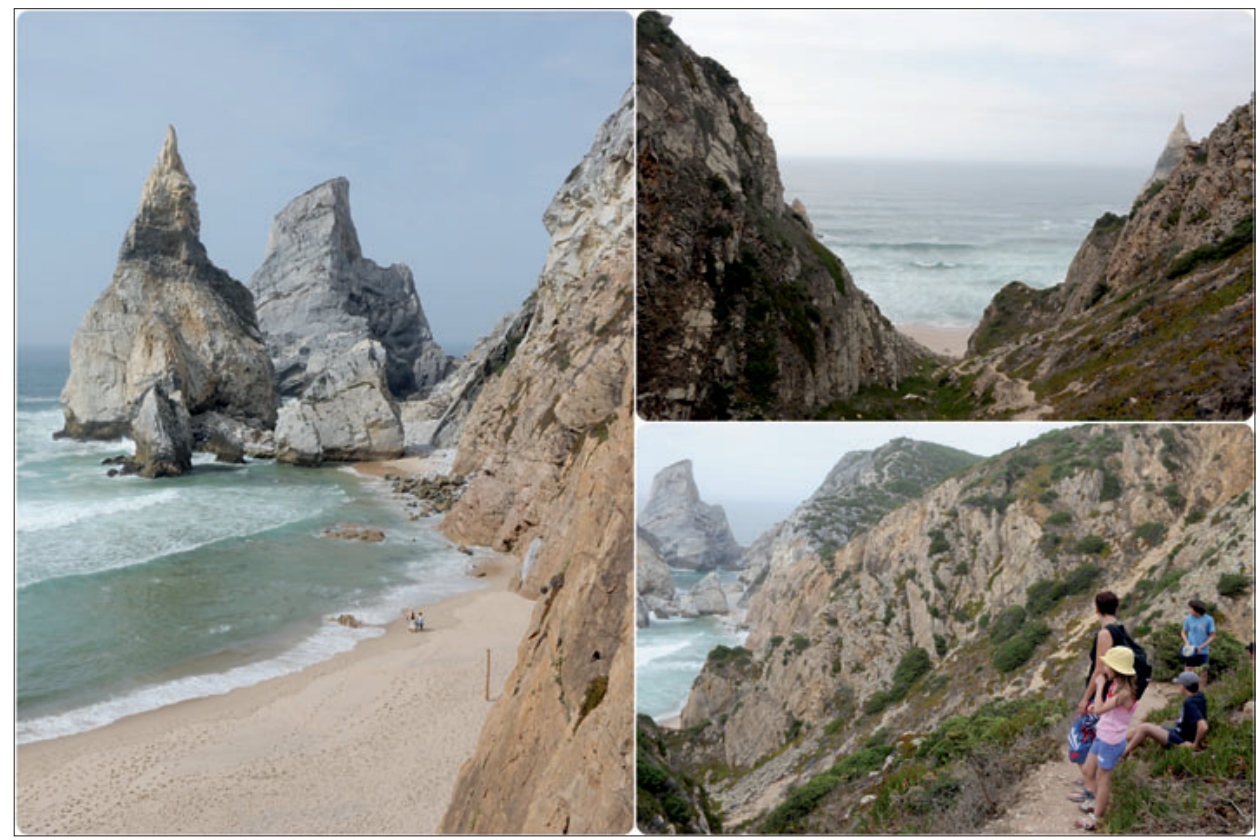

Fot. 3. Praia da Ursa (Portugalia) (fot. J. Latosińska)

Photo 3. Praia da Ursa (Portugal) (photo: J. Latosińska)

oraz punkty z pamiątkami. To bardzo ciekawa atrakcja wykorzystująca skandynawskie podania i legendy (fot. 4).

\section{ATRAKCJE PUNKTOWE}

1) Ongijn Chijd to klasztor buddyjski w Mongolii (Prowincji Ajmak Środkowogobijski), wybudowany w XVII i XVIII w. jako kompleks 28 świątyń. W klasztorze mieszkało ponad tysiąc mnichów. Zniszczony pod koniec lat trzydziestych XX w., a następnie odbudowany. Obiekt „wtopiony” jest w naturalny krajobraz (pustynia), udostępniony do zwiedzania i chętnie odwiedzany. W pobliżu znajduje się pole campingowe Tsagaan Ovoo Camp, gdzie proponowany jest nocleg w tradycyjnych jurtach mongolskich, zawierających jedynie podstawowe wyposażenie (brak światła, limitowana woda, skromne pomieszczenia sanitarne). Camping prowadzony jest przez miejscową ludność. Atrakcja została przygotowana i udostępniona z dbałością o zachowanie krajobrazu naturalnego i kulturowego. Jest chętnie odwiedzana i postrzegana pozytywnie (fot. 5).

2) Pomnik Odkryć Geograficznych i wieża w Belem, neogotycka winda i zabytkowe tramwaje w Baixa to obiekty w Lizbonie, które zostały bardzo dobrze wkomponowane w krajobraz miejski i stały się symbolami stolicy Portugalii. 


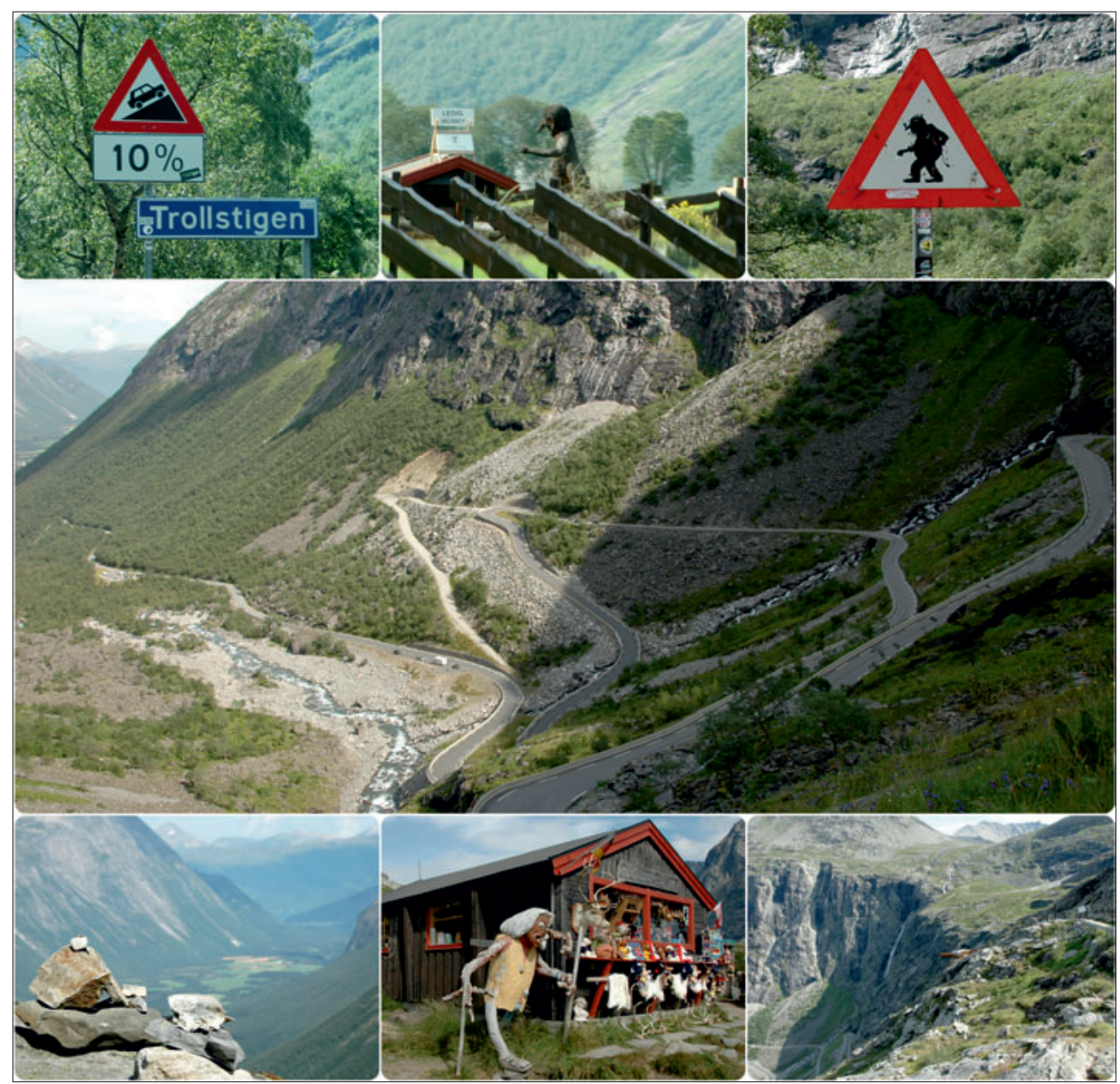

Fot. 4. Trollstigen (Norwegia) (fot. B. Meyer)

Photo 4. Trollstigen (Norway) (photo: B. Meyer)

Obiekty te nawiązują do przeszłości kraju (wieża i pomnik), ale mają też charakter użytkowy uwzględniający położenie Lizbony i konfigurację terenu (winda i tramwaje). Jedne z tych atrakcji są podziwiane, a inne chętnie wykorzystywane przez turystów w celach komunikacyjnych (fot. 6).

\section{Konsekwencje negatywne}

\section{ATRAKCJE POWIERZCHNIOWE}

1) Krokusy w Szczecinie - województwo zachodniopomorskie (Polska). Tak jak Holandia ma swoje tulipany, tak Szczecin ma krokusy. Oczywiście skala 


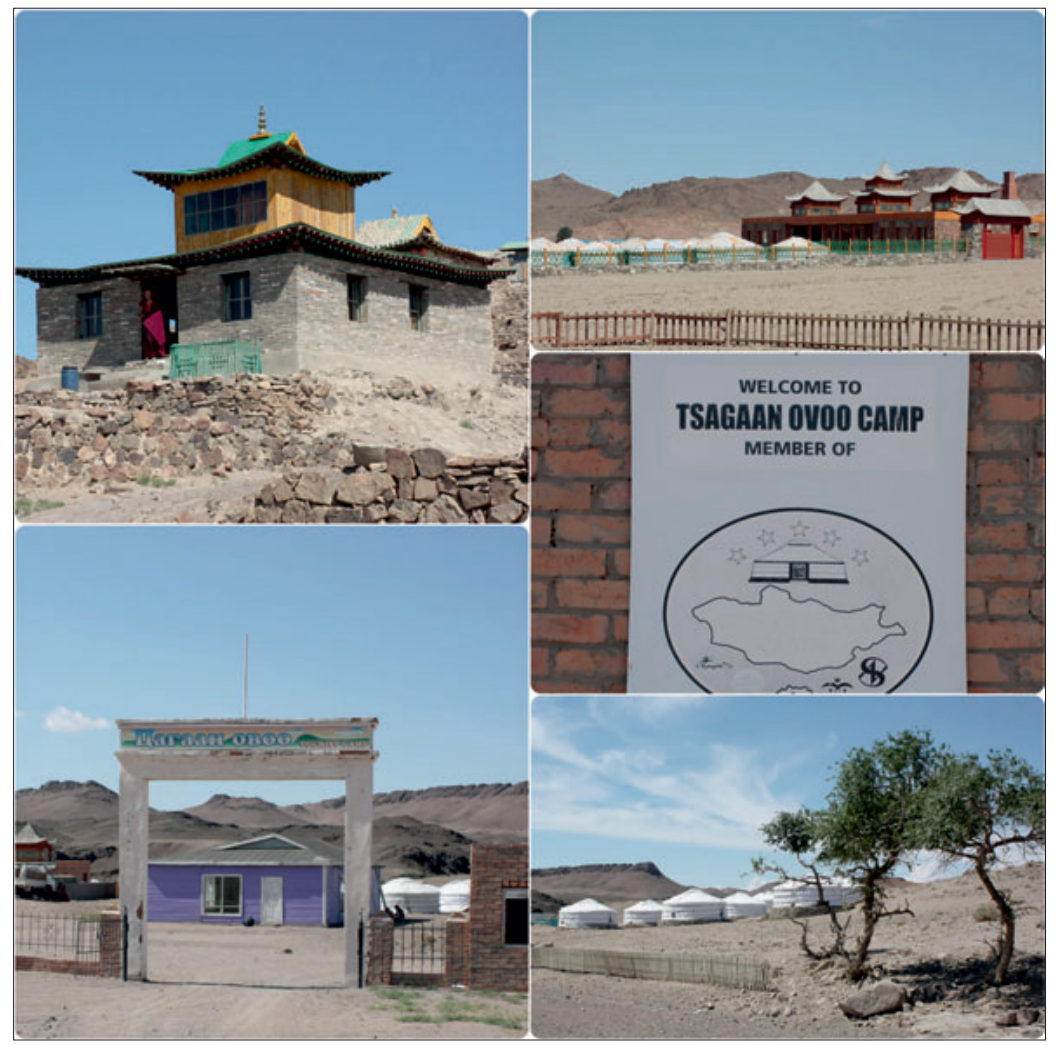

Fot. 5. Ongijn Chijd (Mongolia) (fot. B. Krakowiak)

Photo 5. Ongijn Chijd (Mongolia) (photo: B. Krakowiak)

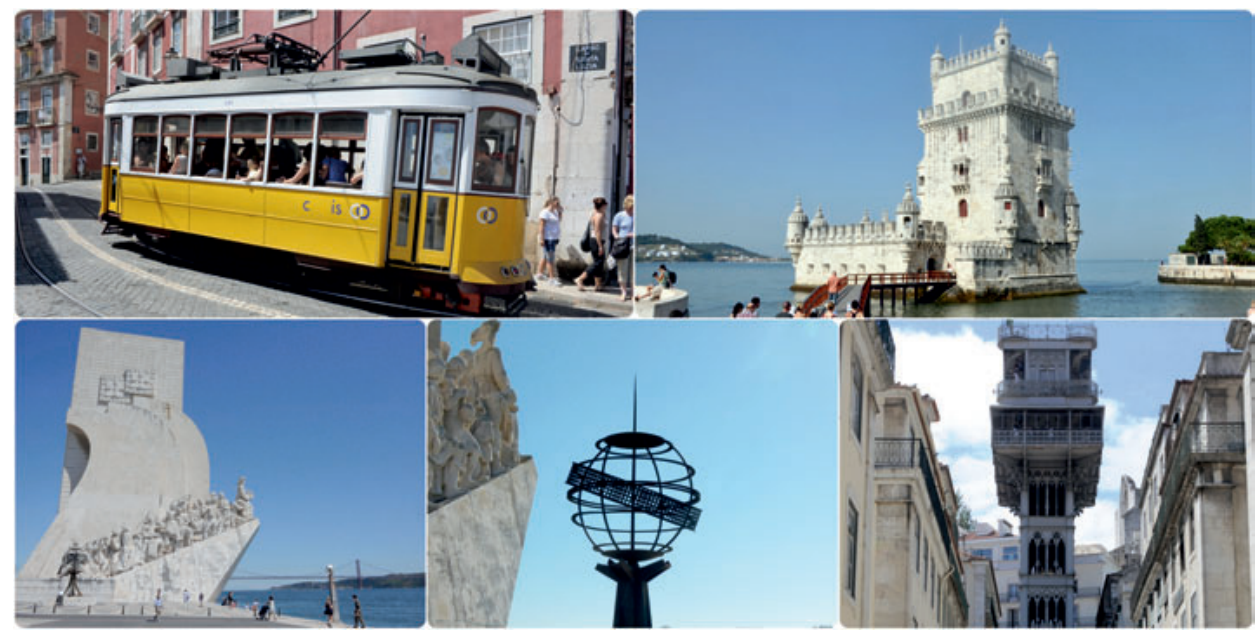

Fot. 6. Lizbona (Portugalia) (fot. J. Latosińska, B. Meyer)

Photo 6. Lizbona (Portugal) (photo: J. Latosińska, B. Meyer) 
zjawiska jest nieporównywalna, ale gdy tylko kwiaty zakwitna, przyciągają mieszkańców i turystów. Ta wykreowana, sezonowa atrakcja w mieście cieszy się dużym zainteresowaniem, niestety jest niszczona przez chętnych jak najbliższego kontaktu z kwiatowym dywanem (fot. 7). Oczywiście najbardziej znane medialnie są krokusy w Tatrach w Dolinie Chochołowskiej, gdzie pojawia się konflikt pomiędzy turystami a Tatrzańskim Parkiem Narodowym.

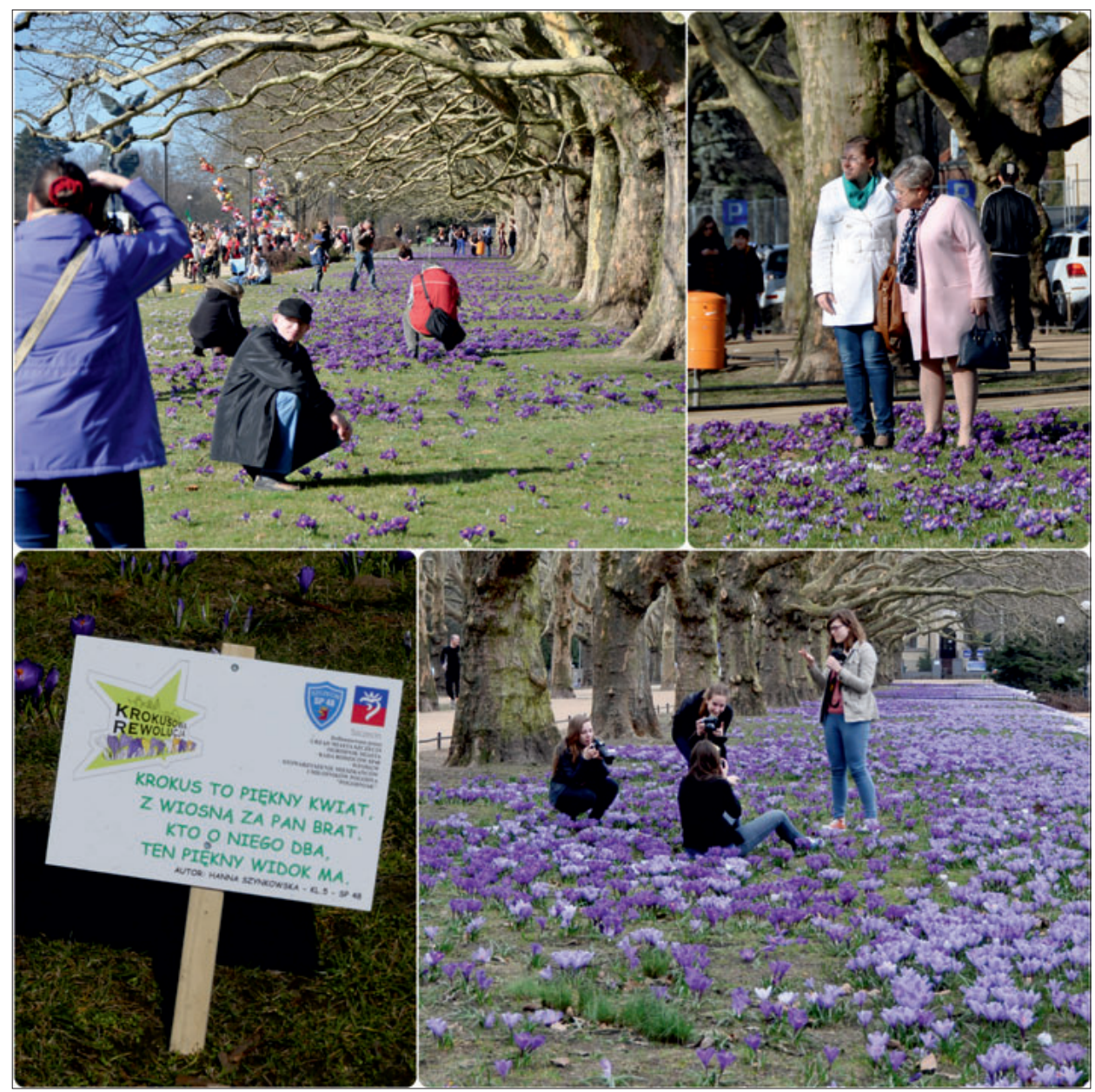

Fot. 7. Szczecin (Polska) (fot. B. Meyer)

Photo 7. Szczecin (Poland) (photo: B. Meyer)

2) Pamukkale (Bawełniana Twierdza) to miejscowość położona w dolinie Cürüksu (Turcja). Słynie z gorących źródeł i wapiennych osadów powstałych na zboczu góry Cökelez. Nacieki układają się w przeróżne formy, tworzą progi, baseny wody termalnej, tarasy. Powstało zagospodarowanie turystyczne, a nadmierna 
liczba turystów spowodowała degradację środowiska naturalnego. Obecnie jest to obszar chroniony i dostępny dla turystów w ograniczonym zakresie (fot. 8).

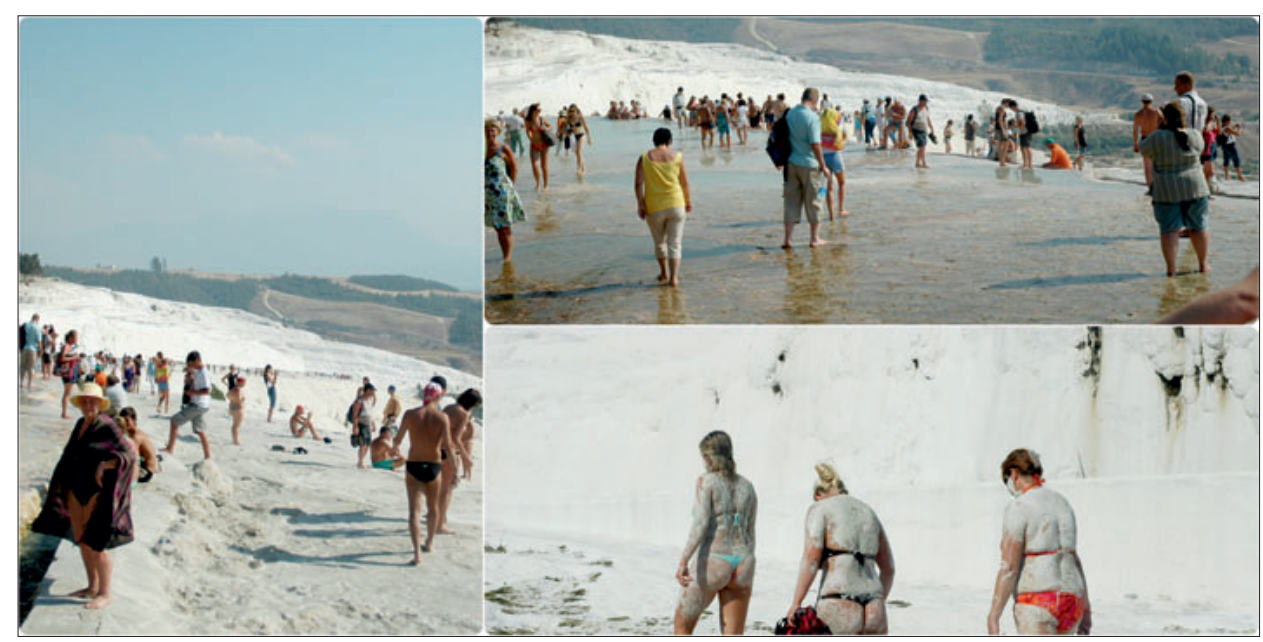

Fot. 8. Pamukkale (Turcja) (fot. B. Meyer)

Photo 8. Pamukkale (Turkey) (photo: B. Meyer)

ATRAKCJE LINIOWE

1) Costa del Sol to region turystyczny w Andaluzji (Hiszpania) obejmujący wybrzeże śródziemnomorskie między Gibraltarem a Przylądkiem Cabo de Gata. Znajduje się tu wiele znanych kąpielisk morskich. Krajobraz naturalny został przekształcony dla celów turystycznych. Oczywiście region przyciąga odwiedzających ciepłym klimatem, ale odpycha zurbanizowaną przestrzenią i thumem wypoczywających. Niestety, w tym przypadku konsekwencje przekształcenia krajobrazu są postrzegane bardzo negatywnie (fot. 9).

2) Plaże - Rimini (Włochy) i Alanya (Turcja). Rimini to jedno z najpopularniejszych miast turystyczno-wypoczynkowych nad północnym Adriatykiem, a Alanya nad Morzem Śródziemnym. To miejscowości obudowane setkami hoteli, restauracji i barów, do których przybywają turyści z całego świata. Magnesem jest ciepły klimat, dobre zagospodarowanie i może przystępna cena. W wyniku nadmiernej eksploatacji tego naturalnego niegdyś krajobrazu mamy do czynienia z zatłoczonymi ponad miarę plażami i miejscowościami (fot. 10).

\section{ATRAKCJE PUNKTOWE}

1) Trzęsacz to nadmorska miejscowość w województwie zachodniopomorskim (Polska). To wieś posiadająca walory wypoczynkowe, ale znana jest 


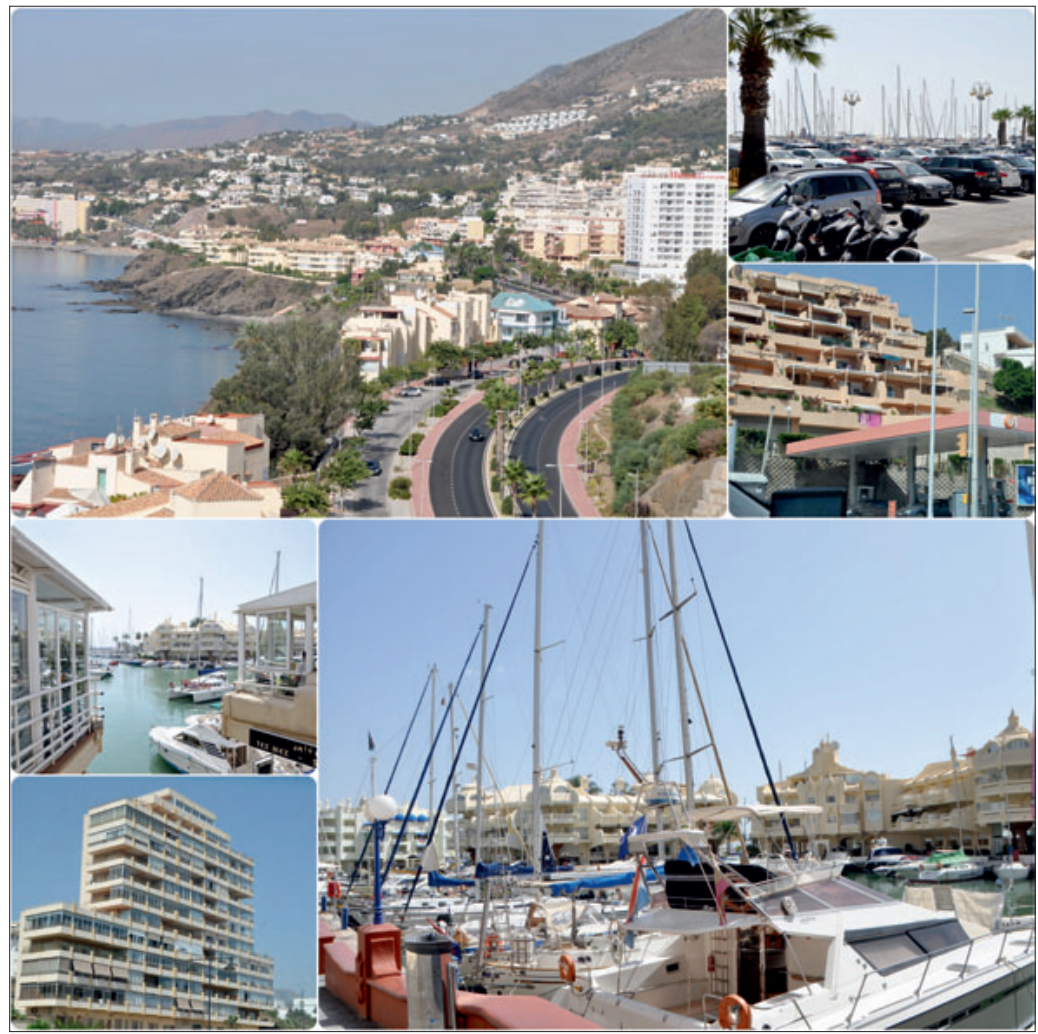

Fot. 9. Costa del Sol (Hiszpania) (fot. B. Meyer)

Photo 9. Costa del Sol (Spain) (photo: B. Meyer)

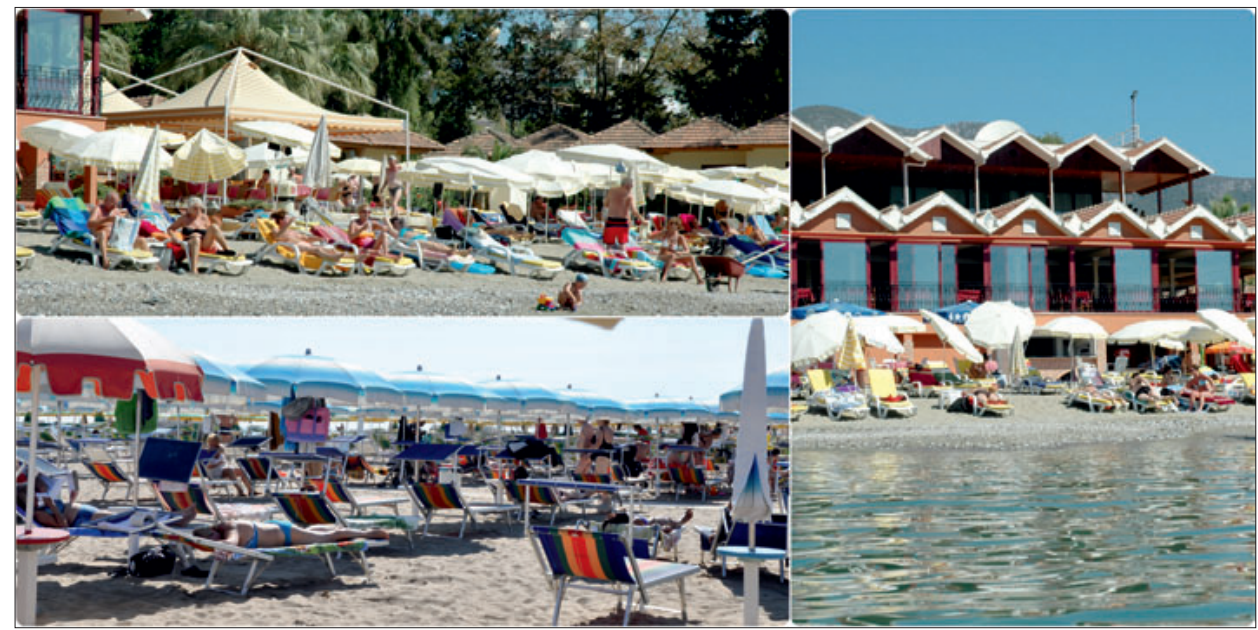

Fot. 10. Rimini (Włochy) i Alanya (Turcja) (fot. B. Meyer)

Photo 10. Rimini (Italy) and Alanya (Turkey) (photo: B. Meyer) 
głównie z jednej atrakcji. Na wysokim brzegu znajdują się ruiny gotyckiego kościoła, który został zniszczony w wyniku cofającego się lądu. W 2009 r. oddano do użytku platformę widokową, umożliwiającą obserwację morza, plaży oraz ruin kościoła. Platforma stała się dominantą tego pięknego krajobrazu, lecz sama go zdecydowanie szpeci (fot. 11).

2) Hotel Gołębiewski w Karpaczu (województwo dolnośląskie, Polska). Karpacz to jedna z najbardziej znanych miejscowości wypoczynkowych w Sudetach Zachodnich, malowniczo wkomponowana w otaczający krajobraz górski. Ten harmonijny porządek w krajobrazie miasta zaburzył hotel Gołębiewski

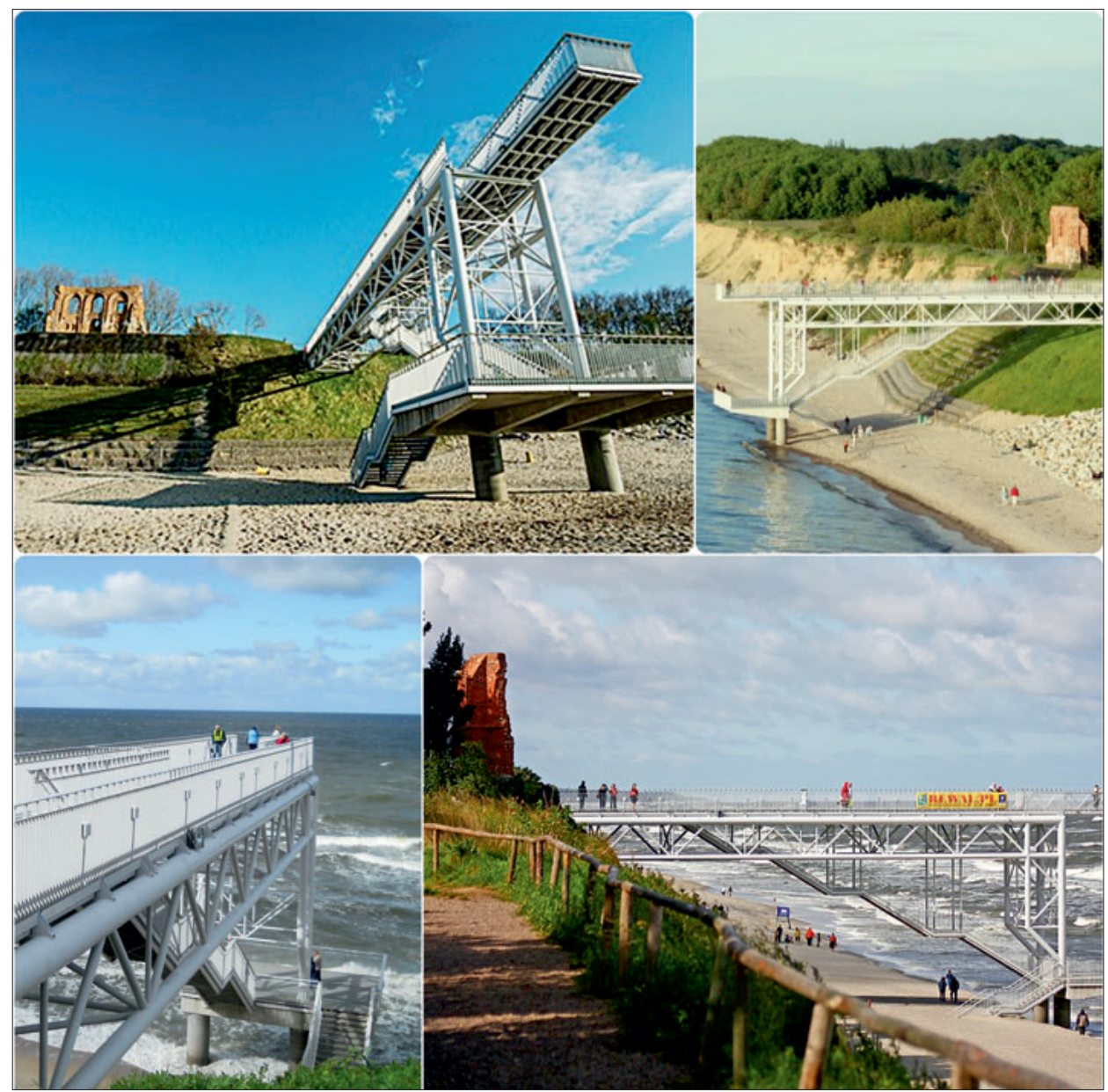

Fot. 11. Trzęsacz (Polska). Źródło: https://www.malypodroznik.pl, https://www.polskaniezwykla. pl, https://poland24h.pl

Photo 11. Trzęsacz (Poland). Source: https://www.malypodroznik.pl, https://www.polskaniezwykla. pl, https://poland24h.pl 
(czterogwiazdkowy), który został wybudowany w eksponowanym miejscu, a jego budowa zniszczyła nie tylko środowisko, ale i panoramę miasta (fot. 12).

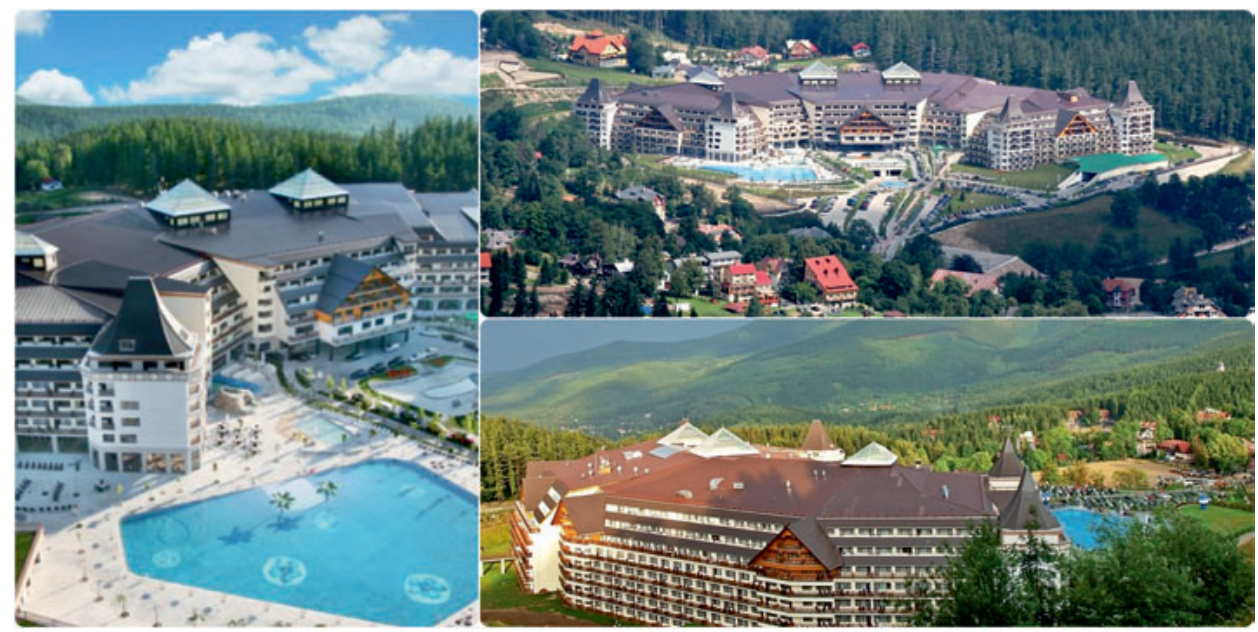

Fot. 12. Hotel Gołębiewski, Karpacz (Polska). Źródło: http://www.spidersweb.pl, http://www. karpacz.com, http://www.hotel-r.net/im/hotel/pl

Photo 12. Hotel Golębiewski, Karpacz (Poland). Source: http://www.spidersweb.pl, http://www. karpacz.com, http://www.hotel-r.net/im/hotel/pl

\section{PODSUMOWANIE}

Artykuł jest próbą zwrócenia uwagi na wykorzystanie krajobrazu dla celów turystycznych, co jest przecież nieuniknione i bardzo wskazane. Można zgodzić się z Lowenthalem (Halling 2011), który uważa, że „krajobrazy osiaggają piękno tylko wtedy, gdy są ożywione przez chuligańskie dzieje ludzkości”, niemniej należy gospodarować środowiskiem w taki sposób, aby dziedzictwo naturalne i kulturowe zachować dla przyszłych pokoleń, należy więc działać zgodnie z zasadami zrównoważonego rozwoju. Udostępnianie atrakcji turystycznych zawsze wiąże się z ingerencją człowieka w środowisko, dlatego bardzo ważne jest, aby pamiętać o minimalizacji negatywnych konsekwencji dla pierwotnego krajobrazu. Europejska Konwencja Krajobrazowa podkreśla, że krajobraz ma kluczowe znaczenie dla dobrobytu społecznego i może być postrzegany jako wyraz dziedzictwa naturalnego i kulturowego oraz podstawa tożsamości.

Rozważając następstwa/skutki podejmowanych przekształceń związanych z turystycznym rozwojem atrakcji o charakterze punktowym, powierzchniowym czy liniowym, można dojść do następujących wniosków: 
1. Pozytywne/neutralne dla krajobrazu konsekwencje przekształcania elementów krajobrazu w atrakcje turystyczne są najbardziej pożądane i z pewnością takie atrakcje będą pozytywnie odbierane przez odwiedzających. $Z$ jednej strony wzbogacają one krajobraz w nowe elementy, chociażby te związane z infrastrukturą turystyczna, ale z drugiej strony krajobraz zachowuje swoją tożsamość, harmonię i ład przestrzenny. To wszystko powoduje bardzo pozytywne emocje wśród turystów, obliguje ich do przestrzegania określonych zasad związanych z udostępnianiem atrakcji i prowokuje do stosownych zachowań.

2. Negatywne dla krajobrazu konsekwencje przekształcania elementów krajobrazu w atrakcje turystyczne są najmniej pożądane, a ich odbiór przez turystów nie zawsze będzie pozytywny. Może być, i pewnie często jest, bardzo negatywny. Takie atrakcje również wzbogacają krajobraz w nowe elementy, ale często tak przekształcony krajobraz traci swoją tożsamość, harmonię i ład przestrzenny. To z kolei może powodować/powoduje negatywne emocje wśród turystów i może prowokować przekraczanie ustalonych zasad i niestosowne zachowania.

Oczywiście przedstawiono skrajne warianty konsekwencji przekształceń związanych z przystosowaniem przestrzeni dla celów turystycznych. Pozostaje jeszcze cała gama relacji pośrednich pomiędzy szeroko rozumianym krajobrazem udostępnionym do zwiedzania a turystami. Można je rozpatrywać w kontekście konsekwencji pozytywnych/neutralnych lub negatywnych, biorąc pod uwagę atrakcje - powierzchniowe, liniowe i punktowe. Mają one bardzo zróżnicowany charakter i mogą być przyczynkiem do badań szczegółowych.

Wkład indywidualny autorów: Jolanta Latosińska - 50\%, Beata Meyer - 50\%.

\section{LITERATURA}

Bastian O., Stein C., Lupp G., Behrens J., Renner C., Grunewald K., 2015: The appreciation of nature and landscape by tourism service providers and visitors in the Ore Mountains (Germany). Landscape online 41:1-23, doi 10.3097/LO.201541.

Bieńczyk G., 2003: Krajoznawstwo i jego związki z turystyką. Wyższa Szkoła Ekonomiczna, Warszawa, 168.

EU, 2000: The European Landscape Convention. The European Union, Council of Europe Treaty Series, 176.

Halling S.-I., 2011: Tourism as interaction of landscapes - opportunities and obstacles on the way to sustainable tourism development in Lamu Island. Kenya, Forskarskolan i Geografii, Kulturgeografiska institutionen, Uppsala Universitet, Uppsala, 118 pp.

Kopaliński W., 1999: Słownik wyrazów obcych i zwrotów obcojęzycznych. Muza SA, Warszawa, 274.

Krakowiak B., Latosińska J., 2012: Historia Łodzi a znaki i symbole w krajobrazie miasta, [w:] J. Łach, A. Zaręba (red.), Studia krajobrazowe. Krajobrazy zdefiniowane - znaki i symbole 
w krajobrazie. Zakład Geografii Regionalnej i Turystyki, Uniwersytet Wrocławski, Wrocław, 143-157.

Kruczek Z., 2005: Metody badania atrakcji turystycznych, [w:] R. Winiarski, W Alejziak (red.). Turystyka w badaniach naukowych, Kraków-Rzeszów, 225-227.

Kruczek Z., 2011: Atrakcje turystyczne. Fenomen. Typologia. Metody badań. Proksenia, Kraków, 200.

Kulczyk S., 2010: „Ginace krajobrazy” a turystyka - wzajemne korzyści czy konflikt?, [w:] D. Chylińska, J. Łach (red.), Studia krajobrazowe, a ginące krajobrazy. Wrocław, 44.

Kulczyk S., 2014: Atrakcyjność turystyczna krajobrazu - przykłady podejścia systemowego. Turystyka Kulturowa, 4, kwiecień 2014, 6-15.

Meyer B., 2008: Krajobraz jako element atrakcyjności turystycznej obszaru, [w:] A. Zaręba, D. Chylińska (red.), Studia krajobrazowe jako podstawa właściwego gospodarowania przestrzenia. Zakład Geografii Regionalnej i Turystyki Uniwersytetu Wrocławskiego, Wrocław, 119-127.

Meyer B., 2012: Dominanty w krajobrazie jako atrakcje przestrzeni turystycznej, [w:] J. Łach, A. Zaręba (red.), Studia krajobrazowe. Krajobrazy zdefiniowane - znaki i symbole w krajobrazie. Zakład Geografii Regionalnej i Turystyki, Uniwersytet Wrocławski, Wrocław, 217-232.

Myga-Piątek U., 2016: Krajobraz jako autentyk, makieta, hybryda. Rozważania o roli krajobrazu we wspótczesnej turystyce. Turystyka Kulturowa, nr 1, styczeń-luty 2016, 47-63.

Pietrzak M., 2008: Krajobraz multisensoryczny i metody jego oceny, [w:] Z. Młynarczyk, A. Zajadacz (red.), Uwarunkowania i plany rozwoju turystyki, Zasoby antropogeniczne, krajobraz, ruch turystyczny. Poznań, 104.

Przecławski K., 1997: Człowiek a turystyka. Zarys socjologii turystyki. Albis, Kraków.

Szulczewska B., 2009: Przyroda, środowisko, krajobraz w planowaniu przestrzennym, [w:] Gospodarka i przestrzeń. Instytut Geografii i Gospodarki Przestrzennej Uniwersytetu Jagiellońskiego, Kraków, 305-319.

Vogt B., Nassery F., 2008: Geometryczne przesłanki zaistnienia dominanty w przestrzeni współczesnego miasta, Czasopismo Techniczne, z. 15, Architektura, z. 6-A, 563.

Wall G., 1997: Tourism attractions: points, lines and areas. Annals of Tourism Research 24 (1), 240-243 https://doi.org/10.1016/S0160-7383(96)00039-4.

Walczak M., 2007: Analiza krajobrazowa w planach ochrony parków krajobrazowych. Ochrona Środowiska i Zasobów Naturalnych, 30, 62. 